Kumawula, Vol. 1, No.1, April 2018, Hal 62 - 74 DOI:http://10.24198/kumawula.v1i1.19485

ISSN 2620-844X (online)

Tersedia online di http://jurnal.unpad.ac.id/kumawula/index

\title{
MEMBANGKITKAN SEMANGAT PEDULI LINGKUNGAN MELALUI PENGOLAHAN LIMBAH BAHAN BERBAHAYA DAN BERACUN (B3) RUMAH TANGGA DI RANCAEKEK
}

\author{
Hasan Sidik $^{\mathbf{1}^{*}}$, Neneng Konety ${ }^{2}$, Savitri Aditiany ${ }^{3}$ \\ 1, 2, ${ }^{3}$ Hubungan Internasional Universitas Padjadjaran \\ *hasan.sidik@unpad.ac.id
}

\begin{abstract}
This research tries to discuss the processing of Hazardous and Poisonous Substances Waste (B3) in the closest community that is namely household B3 waste. Rancaekek is a sub-district with a large number of industries, for a long time the people of the region felt the negative impact of industrial waste on their environment but did not find an effective solution until now. Therefore this research was conducted with the aim of trying to provide socialization and education regarding the management of B3 waste to the people in the Rancaekek sub-district by practicing at the household level. This is an effort to reduce pollution of B3 waste in this sub-district. The research method used is qualitative and the technique of data collection was carried out by interviewing the people scattered in the Rancaekek area, namely Rancaekek Wetan Village, Rancaekek Kulon and Linggar Village. From this research, the community now understands the basic knowledge of B3 waste which not only comes from industry but also in daily life can not be separated from products containing B3 waste. Through this socialization, the community gained more knowledge about the types of B3 waste explained by the Government Regulation No. 85 of 1999. Then also an explanation of the management of household B3 waste in order to reduce the impact of household B3 waste by referring to the rules of Government Regulation No.101 of 2014. The stages of B3 waste management consist of: a) Temporary Storage of B3 Waste; b) Transport of B3 Waste; and c) B3 Waste Storage and Collection.
\end{abstract}

Kata kunci: Limbah B3, Lingkungan Hidup, Rancaekek, Rumah Tangga

\section{PENDAHULUAN}

Jawa Barat merupakan salah satu provinsi di Indonesia yang telah berkembang menjadi wilayah industri. Banyaknya jumlah penduduk dan lokasi yang dekat dengan ibu kota Negara menjadikan Jawa Barat wilayah yang strategis sebagai kawasan Industri. Keberadaan industri memiliki peran besar terhadap perkembangan ekonomi di suatu wilayah, salah satunya Kabupaten Bandung. Menurut data Rencana Pembangunan Jangka Menengah Daerah Kabupaten Bandung (RPJMD) tahun 2011, sektor industri di Kabupaten Bandung dari tahun 2006 s.d. 2010 mengalami pertumbuhan mencapai 7,29\% dan dari sembilan sektor lapangan usaha yang ada sektor industri pengolahan berperan paling besar bagi Produk Domestik Regional Bruto (PDRB) kabupaten Bandung. Namun seiring berkembangnya bidang industri juga mempunyai dampak negatif. Pada umumnya masyarakat sekitar lokasi industri merasakan 
keluhan akibat pertumbuhan jumlah industri dan pencemaran udara, air hingga tanah atau lahan warga sekitar akibat dari limbah yang dihasilkan. Pada umunya dapat dikatakan, makin tinggi tingkat produksi dan konsumsi, makin tinggi pula tingkat limbah yang terbentuk. Kota dengan tingkat hidup yang tinggi menghasilkan limbah yang lebih besar daripada kota dengan tinggkat hidup yang rendah. Berdasarkan data tahun 2004 dari Badan Koordinasi Penanaman Modal, terdapat 184 rencana investasi industri dimana industri-industri tersebut diwajibkan menyusun seperti UKL-UPL, izin tetap dan AMDAL sebagai tindak lanjut dari SK persetujuan Penanaman Modal. Hal itu dilakukan sebab diantara jumlah industri tersebut, jumlah industri manufaktur yang berpotensi mencemari lingkungan adalah 105, dimana 39,8 \% nya merupakan industri yang berada di Provinsi Jawa Barat. Industri-industri yang berpotensi mencemari lingkungan meliputi industri minuman ringan, kosmetik, komponen kendaraan bermotor, komponen elektronik, kertas, plastik, percetakan, dan penyamakan kulit. Data dalam laporan ini tidak menggambarkan sektor seperti minyak dan gas bumi, perbankan, asuransi, sewa guna usaha, pertambangan dalam rangka kontrak karya, investasi portofolio, dan investasi rumah tangga (Kementerian Lingkungan Hidup, 2004).

Menurut Peraturan Pemerintah No. 85 tahun 1999, Limbah adalah sisa suatu usaha atau kegiatan. Limbah ini dapat berbentuk padat, cair ataupun gas, baik yang termasuk B3 ataupun yang bukan. Hal yang menjadi perhatian dari limbah adalah dampak dari limbah tersebut baik yang secara langsung ataupun tidak langsung. Sehingga limbah dikelompokkan ke dalam beberapa jenis berdasarkan dampak atau sifatnya, salah satunya apa yang disebut dengan Limbah Bahan Berbahaya dan Beracun. Menurut Peraturan Pemerintah Nomor 101 tahun 2014 tentang Pengelolaan Limbah Bahan Berbahaya dan Beracun atau biasa disebut dengan Limbah B3 ialah zat, energi, dan/atau komponen lain yang karena sifat, konsentrasi dan/atau jumlahnya, baik secara langsung maupun tidak langsung, dapat mencemarkan dan/atau merusak lingkungan hidup, dan/atau membahayakan lingkungan hidup, kesehatan serta kelangsungan hidup manusia dan makhluk lain. Kekhawatiran akan limbah menjadi perhatian penting pemerintah sebagai bentuk perlindungan pada masyarakatnya. Berbagai regulasi baik ditingkat internasional hingga sub-nasional pun dibuat untuk mengatur dan mengendalikan limbah B3 yang berasal dari segala bidang di masyarakat.

Kekhawatiran pencemaran lingkungan dari Limbah B3 dibuktikan dengan apa yang terjadi di daerah aliran sungai terpanjang dan terbesar di Jawa Barat yaitu sungai Citarum. Sejak 2007 sungai Citarum ini dikatakan sebagai salah satu sungai dengan tingkat ketercemaran tertinggi di dunia. Berdasarkan data dari Greenpeace Indonesia, pemantauan terhadap 35 sungai yang 
dilakukan oleh 30 Badan Pengendalian Dampak Lingkungan Daerah (Bapedalda) Provinsi Jawa barat pada tahun 2008 menunjukkan bahwa pada umumnya status mutu air di Indonesia sudah tercemar berat (Greenpeace Indonesia, 2013). Kondisi Citarum menjadi potret kurangnya pengelolaan air permukaan dan pencemaran limbah melalui sungai di Indonesia. Di kelilingi oleh banyak sektor industri manufaktur seperti tekstil, kulit, logam, kimia, farmasi, produk makanan dan minuman dan sebagainya menyebabkan sungai Citarum banyak terkontaminasi limbah yang dibuang tidak sesuai dengan aturan yang berlaku. Dinas Lingkungan Hidup Daerah (DLH) Provinsi Jawa Barat mengonfirmasi bahwa limbah industri jauh lebih intens dalam hal konsentrasi dan mengandung bahan-bahan berbahaya. Sebanyak 48\% industri yang diamati, rata-rata pembuangan limbahnya 10 kali melampaui baku mutu yang telah ditetapkan (Dinas Lingkungan Hidup Provinsi Jawa Barat, 2010). Sejumlah penelitian sudah menunjukan bahwa sungai tersebut terkontaminasi bahan-bahan kimia berbahaya dan beracun dari industri dengan ditemukannya kandungan logam berat seperti cadmium, tembaga, nikel, dan timbal pada dua spesies ikan yang sering dikonsumsi masyarakat.

Rancaekek salah satu kecamatan di Kabupaten Bandung dikenal merupakan wilayah dengan banyaknya industri yang terletak dekat dengan pemukiman masyarakat yang padat penduduk. Kecamatan ini juga menjadi kecamatan yang dilewati oleh jalan penghubung antara Kota Garut dan Tasikmalaya menuju Bandung atau Sumedang. Selain itu sejak puluhan tahun lalu kecamatan Rancaekek ini memiliki sumber utama pengairan atau irigasi sawahnya berasal dari sungai Cikijing dan sungai Cimande, yang mana merupakan dua anak sungai Citarum yang tercemar oleh limbah B3. Dengan adanya pencemaran tersebut, ratusan hektar sawah, kebun, kolam, juga terkontaminasi secara tidak langsung. Permasalahan tercemarnya lingkungan di kawasan ini banyak dikeluhkan masyarakat dan masih terjadi hingga saat ini. Belum ada penyelesaian yang transparan dan efektif hingga saat ini, sedangkan pertanggung jawaban industri terhadap pencemaran lingkungan yang sudah terjadi puluhan tahun tersebut semakin kabur. Permasalahan limbah ini sudah dikeluhkan oleh masyarakat Rancaekek dan sekitar sejak lama, namun belum juga ada perubahan yang berarti karena kompleknya masalah lingkungan diwilayah pabrik yang juga dekat dengan jalan raya dan pemukiman padat penduduk. Masyarakat pun telah melakukan berbagai upaya untuk mengurangi pencemaran yang mereka rasakan di wilayah rumah mereka.

Namun perlu disadari pencemaran Limbah B3 (Bahan Beracun Berbahaya) tidak hanya berasal dari kegiatan industri saja, dalam kehidupan sehari-hari masyarakat juga tidak lepas dari permasalahan limbah-limbah B3 seperti yang berasal dari rumah tangga. Belum banyak 
masyarakat yang menyadari bahwa limbah rumah tangga juga banyak mengandung jenis limbah B3, tentunya limbah rumah tangga ini memiliki jumlah yang tak kalah besar juga dengan limbah industri. Setiap hari nya rumah tangga menghasilkan sisa pembuangan dari pengerjaan kegiatan rumah tangga dari produk-produk yang mengandung bahan beracun dan berbahaya dan terkadang produsen tidak mencantumkan bahan aktif yang digunakan dalam produknya. Produk insektisida atau pestisida, pembersih porselen, kaca, lantai dan anti sumbat adalah beberapa contoh produk rumah tangga yang mengandung B3. Limbah B3 rumah tangga ini lebih mudah membahayakan manusia di rumah itu sendiri, seperti bahan-bahan yang termasuk jenis B3 yang dibuang di tanah halaman rumah dapat mengkontaminasi air dibawah tanah atau tumbuhan-tumbuhan yang tumbuh didekat rumah.

Masalah pencemaran lingkungan limbah B3 telah menjadi sorotan semua Negara termasuk Indonesia. Keikutsertaan Indonesia dalam konvensi Basel 1989 tenteng pengawasan pergerakan limbah B-3 secara internasional, dan keikutsertaan Indonesia pada KTT Bumi di Rio de Janeiro, menunjukan adanya kepedulian terhadap masalah lingkungan. Dalam mengimplementasikan isi konvensi Basel dan KTT Bumi tersebut dibuatlah perangkat hukum di Indonesia khusus mengatur masalah limbah di Indonesia, huum tersebut adalah Peraturan Presiden No. 101 tahun 2014 dan Peraturan Presiden No. 85 tahun 1999. Berdasarkan penjelasan diatas itu pengabdian pada masyarakat ini dilakukan untuk mendorong cara peningkatkan kepedulian dan pengetahuan masyarakat Rancaekek mengenai praktek pemindahan Limbah B3 yang sesuai dengan aturan dimulai dengan ruang lingkup yang lebih kecil yaitu rumah tangga.

\section{METODE}

Artikel ini merupakan hasil dari kegiatan Pengabdian Pada Masyarakat Dosen Integratif (PPMD Integratif) Universitas Padjadjaran yang dilaksanakan di wilayah Kecamatan Rancaekek pada Semester Ganjil 2018/2019 yang berjudul “Sosialisasi Pengelolaan Limbah B3 (Bahan Beracun Berbahaya) Pada Ibu-Ibu Rumah Tangga Di Kec. Rancaekek”. Adapun teknik pengumpulan data dilakukan dengan penelusuran pustaka dan dengan wawancara dengan Camat Rancaekek, Sekmat Rancaekek dan melakukan seminar sosialisasi terhadap masyarakat yang tersebar di wilayah Rancaekek. Sosialisasi ini dilakukan dengan beberapa kali kunjungan ke Kantor Camat Rancaekek dan diakhiri dengan Ceramah dan ibuibu PKK terkait materi Pengelolaan Limbah B3 di Aula Kantor Kecamatan Rancaekek tanggal 5 November 2018. Pengabdian Kepada Masyarakat terintegrasi KKNM di wilayah Rancaekek 
dibatasi dengan hanya beberapa daerah, yaitu Desa Rancaekek Wetan, Rancaekek Kulon dan Desa Linggar, Kecamatan Rancaekek, Bandung, Jawa Barat. Hal ini dilakukan pada wilayah yang berdekatan dengan kawasan industri sehingga sangat erat kaitannya dengan limbah. Selain itu, sesi tanya jawab dalam ceramah menjadi tambahan data dalam laporan Pengabdian Kepada Masyarakat ini.

\section{HASIL DAN PEMBAHASAN}

Kegiatan "Sosialisasi Kesadaran Lingkungan melalui Pengelolaan Limbah B3 (Bahan Beracun Berbahaya) pada Ibu-Ibu Rumah Tangga di Kec. Rancaekek” dilakukan dalam rangka penyuluhan kebutuhan masyarakat yang bermukim didekat Kawasan industri mengenai pentingnya menjaga kualitas lingkungan terutama limbah B3 rumah tangga di kawasan Industri Rancaekek, Bandung. Kegiatan sosialisasi ini diharapkan dapat memberikan manfaat terhadap masyarakat sekitar, terlebih masyarakat kecamatan Rancaekek yang berdekatan dengan lokasi industri dan memiliki riwayat kasus pencemaran lingkungan akibat limbah B3 yang sering terjadi hingga saat ini. Program ini terdiri dari dua kegiatan yang integratif yaitu kegiatan kuliah kerja nyata yang dilakukan oleh mahasiswa dan pengabdian pada masyarakat yang diselengggarakan oleh dosen. Adapun kegiatan sosialisai Limbah B3 ini merupakan pelaksanaan Program Pengabdian pada Masyarakat.

Program Pengabdian pada Masyarakat (PPM) merupakan program yang UNPAD lakukan sebagai rangkaian dari kegiatan Pengabdian Hibah Internal Unpad (HIU) yang kami canangkan sebelumnya dengan topik tentang pengelolaan limbah B3. Judul PPM yang kami lakukan adalah "Sosialisasi Pengelolaan Limbah B3 (Bahan Beracun Berbahaya) pada Ibu-Ibu Rumah Tangga Di Kec. Rancaekek”. Kegiatan PPM ini kami selenggaran secara integratif dengan kegiatan Kuliah Kerja Nyata Mahasiswa (KKNM) Unpad sehingga diharapkan dapat terjalin keberlanjutan dan kebersamaan antara kegiatan dosen dengan mahasiswa. Adapun lokasi KKN yang kami pilih dalam program PPM yakni di Kecamatan Rancaekek dengan target ibu-ibu rumah tangga. Pemilihan lokasi ini didasari oleh keberadaan Universitas Padjadjaran (Unpad) yang ada di Kecamatan Jatinangor sangat berdekatan dengan Kecamatan Rancaekek sehingga muncul harapan untuk dapat memberikan konstribusi dan sinergi dengan masyarakat sekitar kampus. Begitu pula dengan pemilihan ibu-ibu dan masyarakat secara umum sebagai objek PPM dilandasi oleh semangat untuk berbagi pengetahuan dengan para pelaku yang berhubungan langsung dengan limbah terutama limbah rumah tangga yang sering ditemui dalam kehidupan sehari-hari. 


\section{A. Sosialisasi Kesadaran Lingkungan dan Limbah B3}

Kehawatiran akan semakin memburuknya kondisi lingkungan hidup sudah diupayakan untuk diatasi oleh masyarakat internasional melalui berbagai perjanjian internasional mulai dari Deklarasi Stokholm 1972 diikuti oleh Konvensi Basel 1989 yang khusus menyoroti bahaya limbah beracun (hazardous wastes) lalu KTT Bumi di Rio di Janeiro, Brazil tahun 1992 yang membahas komitmen untuk mejadikan bumi lebih baik dan nyaman untuk didiami manusia. Keputusan untuk menyelenggarakan "Conference on Environment and Development" telah ditetapkan sejak 1989 oleh Majlis Umum PBB (Stone, 1992). Masalah lingkunan telah menjadi isu internasional sejak penyelenggaraan konferensi Stockholm 1972, bahkan sebelum konferensi ini diadakan, negara negara maju telah lama disibukkan dengan masalah pencemaran di negaranya masing masing. Pandangan dan gagasan diadakan konferensi Stockholm dimulai dari adanya kekhawatiran negara negara didunia melihat tingkat pencemaran yang semakin tinggi dan merusak lingkungan hidup manusia sebagai akibat dari industrialisasi. Masalah pencemaran menjadi sinonim dengan lingkungan (Sumarwoto, 1992).

Permasalahan pencemaran lingkungan biasanya menjadi perhatian pemerintah dengan pelaku industri. Namun terkadang tidak terlibatnya masyarakat yang menyebabkan kurang terpantaunya pencegahan pencemaran lingkungan. Masyarakat pada umumnya masih memiliki kesadaran dan pengetahuan yang sedikit mengenai limbah B3 rumah tangga yang sering mereka temui dalam kehidupan sehari-hari. Dari mulai jenis, dampak hingga praktek pemindahan limbah B3 yang diatur berdasarkan hukum nyatanya masih belum banyak masyarakat ketahui, termasuk masyarakat wilayah Rancaekek. Maka dari itu, sosialisasi mengenai bahaya limbah B3 dan bagaimana penangannya kepada masyarakat Rancaekek, khususnya Ibu-ibu yang sering berhadapan langsung dengan limbah rumah tangga menjadi suatu kegiatan yang sangat penting untuk dilakukan, selain untuk menjaga lingkungan, juga untuk keberlanjutan guna meningkatkan kualitas lingkungan yang akan ditempati oleh anak cucu mereka. Maka dari kegiatan sosialisasi, sangat diharapkan timbul semangat peduli terhadap lingkungan dengan tidak membuang limbah sembarangan atau tanpa penyaringan.

Dalam kegiatan sosialisasi Pengelolaan Limbah B3 pada ibu-ibu rumah tangga di Kecamatan Rancaekek ini kami menyampaikan beberapa materi mengenai Limbah B3. Pertama pengenalan limbah B3 itu sendiri, bagaimana yang disebut sebagai Limbah B3, jenis, dampak hingga pengelolaannya berdasarkan hukum. Kami kemudian menjelaskan untuk mengidentifikasi limbah yang ada dimasyarakat termasuk pada limbah B3 atau tidak dibutuhkan uji karakteristik dan uji toksikologi pada limbah tersebut. Dalam Peraturan 
Pemerintah No. 85 Tahun 1999 tentang Pengelolaan Limbah Bahan Berbahaya dan Beracum, dijelaskan identifikasi Limbah B3 menurut sumber dan uji karakteristik atau uji toksikologi. Jenis Limbah B3 menurut sumbernya dijelaskan dalam Pasal 7 ayat 1, yaitu meliputi; a) Limbah B3 dari sumber tidak spesifik; b) Limbah B3 dari sumber spesifik; c) Limbah B3 dari bahan kimia kadaluarsa, tumpahan, bekas kemasan, dan buangan produk yang tidak memenuhi spesifikasi. Kemudian dalam pasal 7 ayat 3 Karakteristik Limbah B3 ini antara lain Limbah yang bersifat: a) mudah meledak; b) mudah terbakar; c) bersifat reaktif; d) beracun; e) menyebabkan infeksi; dan f) bersifat korosif. Walaupun dalam hasil identifikasi limbah tersebut tidak menunjukan bukan Limbah B3, pengelolaan limbah tersebut tetap harus sesuai dengan ketentuan.

Indonesia merupakan salah satu negara yang wajib mengelola limbah B3 (Bahan Beracun Berbahaya), selain karena Indonesia memiliki berbagai macam industri dan manufaktur, Indonesia juga telah meratifikasi Konvensi Basel tentang Pengawasan Pergerakan Lintas Batas Limbah Berbahaya dan pembuangannya tahun 1989, sehingga Indonesia harus menaati hukum Internasional yang berlaku mengenai pengelolaan Limbah B3.

Indonesia memiliki BAPEDAL (Badan Pengendalian Dampak Lingkungan) sebagai Competent authority dan Direktorat Pengelolaan Limbah dan Bahan Berbahaya Beracun BAPEDAL sebagai Focal Point. Mereka merupakan lembaga pemerintah yang memiliki wewenang cukup luas terkait kegiatan limbah B3. Adapun kewenangannya meliputi:

a. Membuat peraturan teknis tentang limbah

b. Memberikan izin pengelolaan limbah B3

c. Berkoordinasi dengan sekretariat Konvensi Basel di Swiss

d. Menetapkan bentuk-bentuk pelanggaran atas pengelolaan limbah B3

Adapun pengelolaan Limbah B3 terdiri dari Pengumpulan, Penimbunan, Pengolahan, Pemanfaatan, dan pengangkutan. Dalam pengumpulan, perusahaan harus memenuhi izin kewenangan dari otoritas setempat yang berlaku. Untuk skala kabupaten atau kota, harus atas izin kewenangan bupati atau wali kota, kecuali Oli Bekas harus memenuhi izin dari KLH. Skala provinsi harus memiliki izin kewenangan dari Gubernur dan skala nasional dari Menteri Lingkungan Hidup. Untuk tahap penimbunan, dan pengolahan harus berdasarkan izin kewenangan Menteri Lingkungan Hidup. Sedangkan dalam proses pemanfaatan ada dua kriteria, yakni Pemanfaatan bukan kegiatan utama, izin dari KLH/Menteri LH dan Pemanfaatan sebagai kegiatan Utama Izin dari Menteri Perindustrian setelah mendapat rekomendasi dari Menteri LH. Pengangkutan sebagai kegiatan utama/bukan sebagai kegiaatan utama: Izin 
kewenangan Menteri Perhubungan setelah mendapat Rekomendasi dari KLH. Berikut flow chart kewenangan perizinan dalam pengelolaan limbah B3:

Di Indonesia, terdapat sekitar 43 macam limbah B3 yang sebagian besar berupa limbah kimiawi, yang berasal dari industri tekstil, limbah rumah sakit, limbah industri cat, dan lainlain industri yang menggunakan bahan-bahan kimia. Selain limbah yang biasanya terdapat dari pablik atau industri, limbah-limbah yang berasal dari rumah tangga yang tidak dikendalikan dapat menyebabkan penurunan kualitas lingkungan. Limbah-limbah yang paling berbahaya bagi lingkungan adalah jenis limbah yang dapat meledak pada kondisi tertentu. Selain membahayakan lingkungan, juga berbahaya bagi keselamatan manusia jika limbah tersebut meledak di kawasan yang ramai penduduk atau terdapat bahan-bahan yang mudah terbakar.

Tabel 1. Pengelompokan Limbah B3 Rumah Tangga

\begin{tabular}{|l|l|l|}
\hline No & \multicolumn{1}{|c|}{ Sumber } & \multicolumn{1}{|c|}{ Produk yang Berpotensi Menjadi Limbah B3 } \\
\hline 1 & Kebutuhan di Dapur & $\begin{array}{l}\text { Pembersih alat makan, Pembersih lantai, Kompor Gas, Pembersih } \\
\text { kaca, Plastik, Racun Tikus, Bubuk Pembersih, Pembuka Sumbat, } \\
\text { Saluran Air Kotor. }\end{array}$ \\
\hline 2 & $\begin{array}{l}\text { Kebutuhan dalam kegiatan } \\
\text { mencuci. }\end{array}$ & $\begin{array}{l}\text { Pemutih, Deterjen, Pembersih Lantai, Bahan Pencelup, Semir } \\
\text { Sepatu, Pembersih Karpet, Pembuka Sumbat, Saluran Air Kotor. }\end{array}$ \\
\hline 3 & Kebutuhan di Kamar Mandi & $\begin{array}{l}\text { Aerosol, Desinfektan, Pembuka Sumbat, Saluran Air Kotor, } \\
\text { Pembersih lantai dan Kaca, Hair Spray, Pewarna Rambut, } \\
\text { Pembersih Toilet, Kamper, Medicated Shampoo. }\end{array}$ \\
\hline 4 & Kebutuhan di Kamar Tidur & $\begin{array}{l}\text { Kamper, Pembersih Karpet, Pembersih Mebel, Pembersih Lantai, } \\
\text { Pembersih Kaca, Semir Sepatu, Obat Anti Nyamuk, Batere, } \\
\text { Pembersih Lantai, Aerosol, Cat Kuku dan Pembersih. }\end{array}$ \\
\hline 5 & Garasi dan Gudang & $\begin{array}{l}\text { Oli, Aki Mobil, Minyak Rem, Car wax, Pembersih Karburator, Cat } \\
\text { dan Thinner, Lem, Pembunuh Tikus, Genteng Asbes. }\end{array}$ \\
\hline 6 & Ruang Tamu & $\begin{array}{l}\text { Pengharum Ruangan, Pembersih Karpet, Pembersih Mebel, } \\
\text { Pembersih Kaca. }\end{array}$ \\
\hline 7 & Kebutuhan Taman & Pupuk, Insektisida. \\
\hline 8 & Makanan dan Kosmetik & Obat Kadaluarsa, kosmetik yang mengandung merkuri. \\
\hline
\end{tabular}

Sumber : Anggana, 2013

Kemudian sesudah penjelasan mengenai jenis limbah B3, dalam sosialisasi ini kami menjelaskan pada prakter pengelolaan limbah B3 yang diatur dalam Peraturan Pemerintah No. 101 tahun 2014. Dalam melindungi masyarakat dari dampak serta gejala kerusakan lingkungan hidup akibat dari limbah B3 ini, pemerintah melakukan regulasi dalam pengumpul, pengangkut, pemusnah dan pengolahan limbah B3 di wilayah Provinsi maupun Kabupaten/Kota yang diatur dalam Peraturan Pemerintah No. 101 Tahun 2014 tentang Pengelolaan Limbah Bahan Berbahaya dan Beracun. Pengelolaan Limbah B3 terdiri dari Pengumpulan, Penimbunan, Pengolahan, Pemanfaatan, dan pengangkutan. 
Dalam melakukan pengelolaan limbah B3 perlu diperhatikan hirarki pengelolaan limbah B3 antara lain dengan mengupayakan reduksi pada sumber, pengolahan bahan, substitusi bahan, pengaturan operasi kegiatan, dan digunakannya teknologi bersih. Bilamana masih dihasilkan limbah B3 maka diupayakan pemanfaatan limbah B3. Pemanfaatan limbah B3, yang mencakup kegiatan daur ulang (recycling), perolehan kembali (recovery) dan penggunaan kembali (reuse) merupakan satu mata rantai penting dalam pengelolaan limbah B3. Dengan teknologi pemanfaatan limbah B3 di satu pihak dapat dikurangi jumlah limbah B3 sehingga biaya pengolahan limbah B3 juga dapat ditekan dan di lain pihak akan dapat meningkatkan kemanfaatan bahan baku. Hal ini pada gilirannya akan mengurangi kecepatan pengurasan sumber daya alam (Peraturan Pemerintah No. 85 Tahun 1999). Dalam pengelolaan Limbah B3 terdapat beberapa rangkaian yang mencakup kegiatan:

a. Penyimpanan Sementara Limbah B3

b. Pengumpulan

c. Pengangkutan Limbah B3

d. Pengolahan

e. Penyimpanan atau Penimbunan hasil Pengolahan.

Dalam pengumpulan, perusahaan harus memenuhi izin kewenangan atau rekomendasi operasi dari kepala instansi yang bertanggung jawab di wilayah setempat. Ketentuan dan tata cara memperoleh izin/rekomendasi tersebut harus sesuai dengan Kep-68/Bapedal/05/1994. Perizinan pengelolaan limbah B3 dimaksudkan untuk mengetahui jumlah/timbunan, jenis, karakteristik dan peredaran Limbah B3 di Indonesia dari sejak dikumpulkan sampai dengan pengolahan akhir. Untuk skala kabupaten atau kota, perizinan harus atas izin kewenangan bupati atau wali kota, kecuali Oli Bekas harus memenuhi izin dari KLH. Skala provinsi harus memiliki izin kewenangan dari Gubernur dan skala nasional dari Menteri Lingkungan Hidup. Untuk tahap penimbunan, dan pengolahan harus berdasarkan izin kewenangan Menteri Lingkungan Hidup. Sedangkan dalam proses pemanfaatan ada dua kriteria, yakni Pemanfaatan bukan kegiatan utama, izin dari KLH/Menteri LH dan Pemanfaatan sebagai kegiatan Utama Izin dari Menteri Perindustrian setelah mendapat rekomendasi dari Menteri LH. Pengangkutan sebagai kegiatan utama/bukan sebagai kegiaatan utama: Izin kewenangan Menteri Perhubungan setelah mendapat Rekomendasi dari KLH. Berikut flow chart kewenangan perizinan dalam pengelolaan limbah B3: 


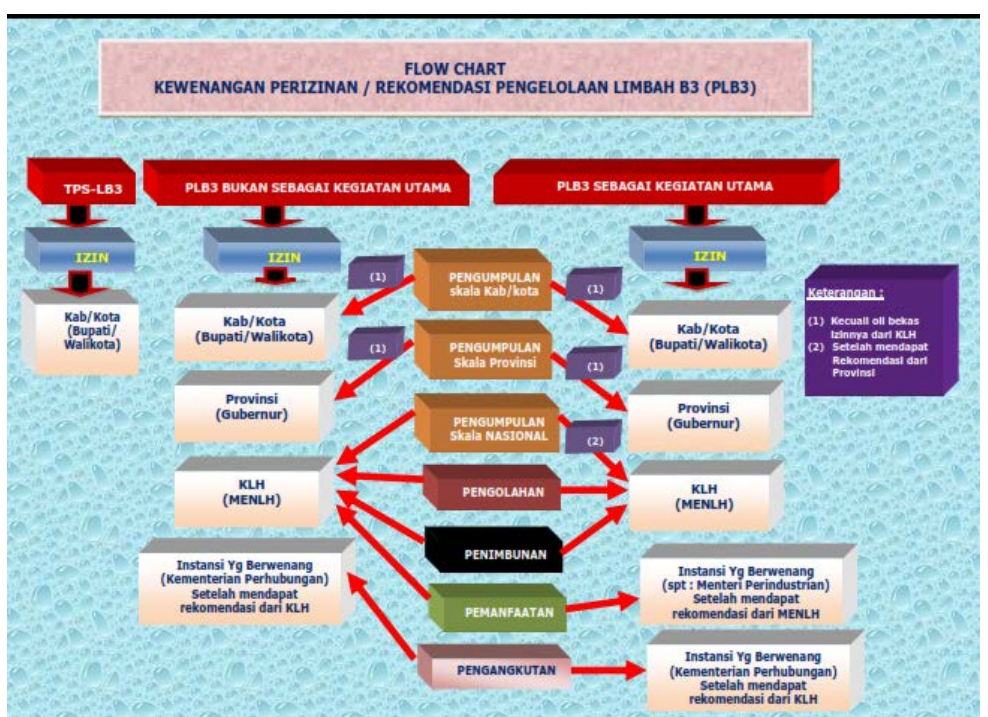

Gambar 1: Penjelasan mengenai izin Kewenangan Pengelolaan Limbah B3(Bapedal:2009)

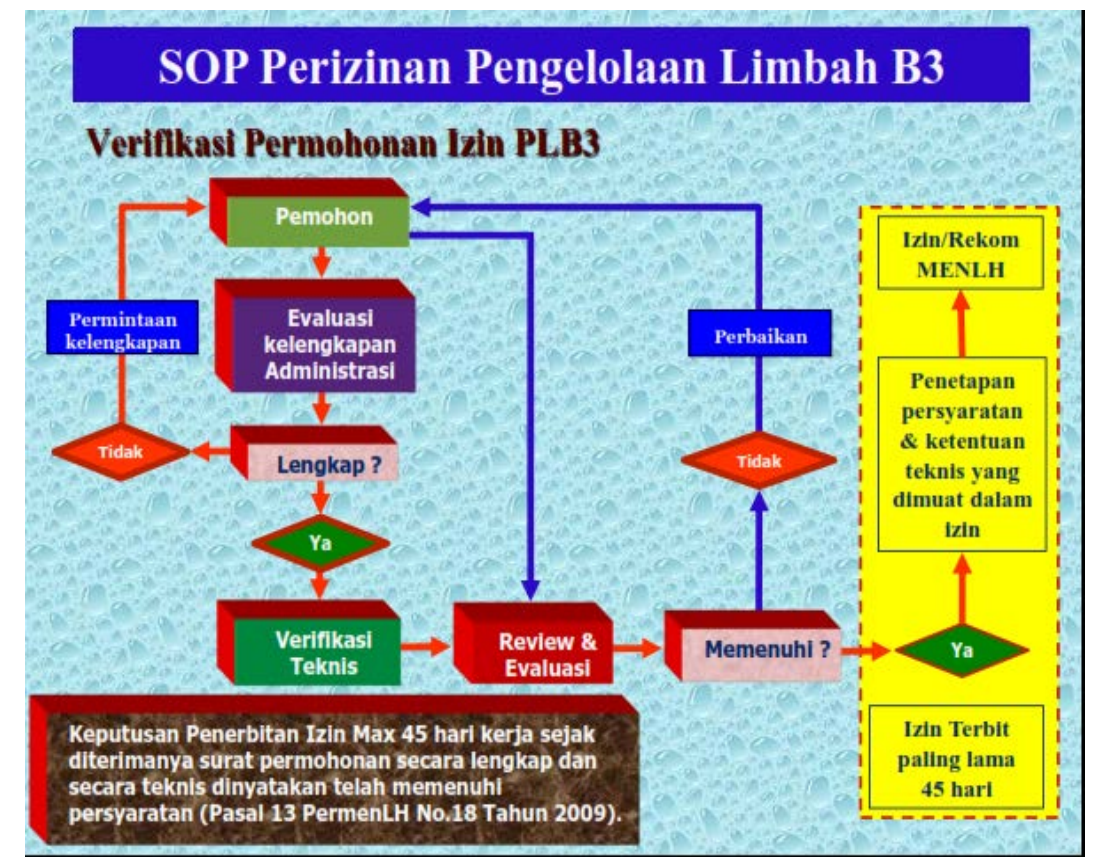

Gambar 2: Standar Operasional Pengelolaan Limbah B3(Bepedal;2009)

Limbah B3 yang dapat merusak lingkungan atau menurunkan kualitas lingkungan apabila:

a. Jika dibuang ke tanah

- merusak tanah dan air di dalam nya

- $\quad$ kesuburan tanah rusak sehingga tidak bisa ditanami

- mengancam produksi pertanian

b. jika dibuang ke air (sungai atau danau)

- air tercemar tidak dapat digunakan

- makhluk hidup air mati 
- pasokan air bersih berkurang

Dalam sosialiasi ini, fasilitator menyarankan masyarakat khususnya ibu rumah tangga untuk menghindari pembuangan secara langsung dari rumah tangga ke sungai dengan cara membuat folder. Adapun foldernya adalah sebagai berikut:

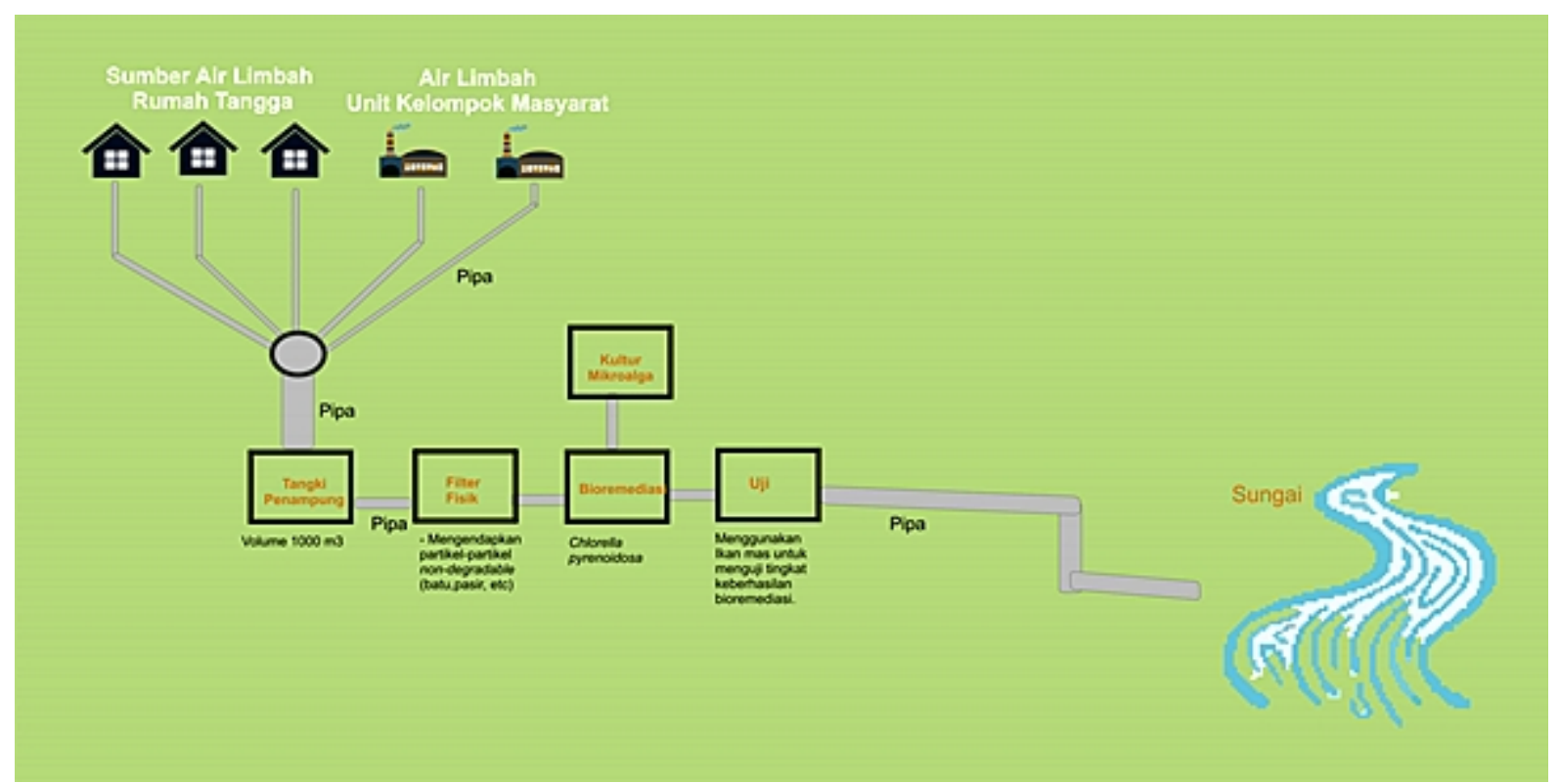

Gambar 3: contoh Folder Pembuangan Limbah Cair ke Sungai (Tim PPM Unpad 2018)

Folder tersebut menunjukkan bagaimana memfilter limbah, sehingga air yang keluar dari folder sudah terbebas dari zat-zat berbahaya dan aman apabila dibuang ke sungai. Adapun bahan yang digunakan cukup mudah dan sering dijumpai, yaitu Sabut Ijuk atau kelapa, Arang, dan Batu kerikil atau split. Dengan adanya folder tersebut, membantu memfasilitasi masyarakat untuk meningkatkan kepeduliannya terhadap lingkungan yang mereka tempati saat ini. Selain mudah digunakan, folder ini juga tidak memakan biaya yang besar. Antusiasme masyarakat dalam kegiatan sosialisasi ini memberikan harapan besar untuk lingkungan yang lebih baik di masa mendatang.

\section{SIMPULAN}

Dari Pengabdian Kepada Masyarakat ini menunjukan bahwa praktek menjaga lingkungan dari limbah bahan berbahaya dan beracun (B3) perlu dilakukan juga dalam lingkup rumah tangga. Betapa pentingnya menjaga lingkungan dengan melakukan pengelolaan limbah B3 dari rumah tangga untuk mencegah dampak berbahaya secara langsung pada masyarakat. Melalui sosialisai 
ini, masyarakat terutama ibu-ibu di kecamatan Rancaekek mendapat ilmu lebih mengenai jenis dan dampak limbah B3 berdasarkan Peraturan Pemerintah No. 85 tahun 1999, dalam sosialisasi ini dikelompokan produk-produk yang biasa digunakan dalam rumah tangga kehidupan seharihari yang termasuk pada jenis limbah B3. Kemudian melalui sosialisasi ini juga dijelaskan mengenai cara pemindahan serta pengelolaan yang benar sesuai dengan aturan yang berlaku yaitu Peraturan Pemerintah No. 101 tahun 2014, dengan begitu akan mengurangi kemungkinan dampak bahaya dari limbah B3 di sekitar rumah serta mendorong kepedulian masyarakat untuk menjaga kelestarian lingkungan.

\section{UCAPAN TERIMAKASIH}

Terima kasih yang setinggi-tingginya kami haturkan kepada para mahasiswa kami yang tergabung dalam program KKNM-PPM Integratif 2018 di Kecamatan Rancaekek atas kontribusinya dalam Pengabdian ini dan pelaksanaan Pengabdian Kepada Masyarakat.

\section{DAFTAR PUSTAKA}

Anggana, R. D. (2013). Sampah B3 (Bahan Berbahaya dan Beracun) Rumah Tangga. Retrieved November 10, 2018, from http://www.banksampahmelatibersih.com/2013/02/sampah-b3-bahan-berbahaya-danberacun.html\#.XAE5QTExXIV

Badan Pengendalian Lingkungan Hidup (Bapedal) Kementrian ingkungan Hidup Republik Indonesia, (2009), Manajemen Pengolahan Limbah B3, Jakarta.

Dinas Lingkungan Hidup Provinsi Jawa Barat. (2010). Status lingkungan Hidup Daerah: Aktivitas Industri dengan Kemungkinan Kontaminasi Air. Bandung: Dinas Lingkungan Hidup Provinsi Jawa Barat.

Greenpeace Indonesia. (2013). Citarum Nadiku Mari Rebut Kembali. Retrieved November 26, 2018, from http://www.greenpeace.org/seasia/id/campaigns/toxics/Air/citarum/

Kementerian Lingkungan Hidup. (2004). Status Lingkungan Hidup. Jakarta: Kementerian Lingkungan Hidup.

Peraturan Pemerintah No. 101 Tahun 2014 Tentang Pengelolaan Limbah Bahan Berbahaya dan Beracun. Jakarta. 
Peraturan Pemerintah No. 85 Tahun 1999 Tentang Perubahan Atas Peraturan Pemerintah Nomor 18 Tahun 1999 Tentang Pengelolaan Limbah Bahan Berbahaya dan Beracun. Jakarta.

Stone, C. D. (1992). Beyond Rio: Insuring Global Warming. American Journal of Internatioal Law, 86(3), 445.

Sumarwoto, O. (1992). Dari Stockholm Ke Rio Implikasinya Bagi Pembangunan Nasional. Bandung: Unpad.

Undang-Undang Republik Indonesia Nomor 32 tahun 2009 tentang Pengelolaan Lingkungan Hidup

Surat Keputusan Menteri Perindustrian Republik Indonesia Nomor 231/MPP/KP/07/1997 tentang Prosedur Impor Limbah 